Exemplary Novels 
This page intentionally left blank 


\section{Exemplary Novels}

MIGUEL DE CERVANTES

TRANSLATED FROM THE SPANISH

BY EDITH GROSSMAN

EDITED BY ROBERTO GONZÁLEZ ECHEVARRÍA

YALE UNIVERSITY PRESS 1 NEW HAVEN \& LONDON

\section{A MARGELLOS}


The Margellos World Republic of Letters is dedicated to making literary works from around the globe available in English through translation. It brings to the English-speaking world the work of leading poets, novelists, essayists, philosophers, and playwrights from Europe, Latin America, Africa, Asia, and the Middle East to stimulate international discourse and creative exchange.

English translation and translator's note (C) 2016 by Edith Grossman.

Introduction and notes by Roberto González Echevarría. Copyright (C) 2016 by Yale University. All rights reserved.

This book may not be reproduced, in whole or in part, including illustrations, in any form (beyond that copying permitted by Sections 107 and 108 of the U.S. Copyright Law and except by reviewers for the public press), without written permission from the publishers.

Yale University Press books may be purchased in quantity for educational, business, or promotional use. For information, please e-mail sales.press@yale.edu (U.S. office) or sales@yaleup.co.uk (U.K. office).

Set in Electra and Nobel type by Westchester Publishing Services

Printed in the United States of America.

ISBN 978-0-300-12586-3 (hardcover : alk. paper)

Library of Congress Control Number: 2016937056

A catalogue record for this book is available from the British Library.

This paper meets the requirements of ANSI/NISO Z39.48-1992 (Permanence of Paper).

10987654321 